\title{
EDUCATION SYSTEM OF MODERN ISLAMIC BOARDING SCHOOL IN THE POSTMODERN ERA
}

\author{
Kamaluddin MH Pasi ${ }^{1}$, Rasyidin ${ }^{2}$, Radinal Mukhtar Harahap ${ }^{3}$ \\ Pascasarjana Universitas Islam Negeri Sumatera Utara, Indonesia ${ }^{1}$ \\ Sekolah Tinggi Ilmu Tarbiyah Ar-Raudlatul Hasanah, Indonesia, ${ }^{2,3}$ \\ KMHPasi@gmail.com, rasyidinaja1961@gmail.com, radinalmukhtarhrp@gmail.com
}

\author{
Received: 17-07-2020 Revised: 29-09-2020 Accepted: 03-10-2020
}

\begin{abstract}
This article aims to explore information about Islamic Boarding School (Pesantren) incredibly Modern related to Postmodernism. The traditionalism of Pesantren in the early days is considered to have changed with modernism. The answer to the influence of Postmodernism to be found by the method of description-comparisoninterpretation of the data obtained. The discussion shows that the effect of the movement of thought is only the lexical meaning of renewal. As for Pesantren's principles, characteristics, or fundamental values remains valid and become an institution that becomes a tradition in the body of Islamic Education thinking. It can also be said that the better (al-ashlab) taken by him and keeping the good (al-shâlib), means is his traditions. A tradition that is considered similar to other thought movements is Pesantren's dynamic attitude. Similarly, Waqf is the basis of ownership in Pesantren which replaces the Foundation system. It is not a new item, so its value remains in the Islamic tradition. Thus it can be understood that Pesantren continues to return to the rule of existing Islamic educational institutions, which aims to give the life of the world and the hereafter to everyone related to it.
\end{abstract}

Keywords: Modernism, Postmodernism, Islamic Boarding School, Education System.

\begin{abstract}
Abstrak
Artikel ini bertujuan menggali informasi mengenai Pondok Pesantren, utamanya Modern, terkait Postmodernisme. Tradisionalisme Pondok. Pesantren masa awal dianggap berubah dengan adanya modernisme. Jawaban pengaruh postmodernisme yang hendak ditemukan dengan metode deskripsikomparasi-interpretasi atas data yang diperoleh. Pembahasan menunjukekan bahwa pengaruh gerakan pemikiran tersebut hanya makna leksikal kebaruan saja. Adapun prinsip, asas, ciri khas ataupun nilai-nilai dasar Pondok Pesantren tetap berlaku dan ia menjadi lembaga yang mentradisi dalam tubuh pemikiran Pendidikan Islam. Dapat juga dikatakan babwa yang lebib baik (al-ashlah) diambil olehnya dan tetap menjaga yang baik (al-shâlih) yakni tradisi-tradisinya. Tradisi yang dianggap mirip dengan gerakan pemikiran lainnya merupakan sikap dinamis Pondok Pesantren. Begitu juga mengenai wakaf yang menjadi dasar kepemilikan di Pondok Pesantren yang menggantikan sistem Yayasan. Ia bukan 'barang baru' sehingga nilainya tetap terdapat dalam tradisi Islam. Dengan itu, dapat kiranya dipahami bahwa Pondok Pesantren tetap kembali kepada tradisi lembaga-lembaga pendidikan Islam yang telah ada, yang bertujuan memberi daya kehidupan dunia dan akbirat bagi setiap orang yang bersinggungan padanya.
\end{abstract}

Kata Kunci: Modernisme, Postmodernisme, Pondok Pesantren Modern, Sistem Pendidikan 


\section{INTRODUCTION}

Islamic Boarding School (Pesantren) $)^{1}$ is one of the educational institutions that is characteristic of traditional Education in Indonesia ${ }^{2}$. The institution has been around since the advent of Islam in the Archipelago. ${ }^{3}$ One of the characteristics of his early Education was the cottage whose learning process was done with a direct eye between the teacher or kiai and the students ${ }^{4}$. Pesantren education at that time focused on teaching religious science without including elements of general sciences to call it secular as well. ${ }^{5}$

Over time, the form of Education in Pesantren changed in a more orderly and modern direction. Steenbrink once suggested that the introduction of Pesantren to modernization would result in a lack of students and the inaction of traditional educational institutions. ${ }^{6}$ In fact, as Ibrahim recorded in the statistical data of the Director-General of Islamic education 2010-2011, Pesantren which is termed as salaf is precisely growing and increasing. The existence of traditionalism during the flow of modernization due to kiai's role as a policy determinant in Pesantren. ${ }^{7}$ The same is the case with modern pesantrens that take a stand for change. Azra even placed his modernization stance as the key to edity amid the rapid flow of the emergence of different Islamic educational institutions. ${ }^{8}$ Darussalam Gontor Ponorogo Islamic Boarding School considered the foundation of modernization in the 20th century, described Zarkasyi, did so by integrating the Islamic traditional system together with madrassas, integrating formal, nonformal and informal Education in pesantren, teaching

${ }^{1}$ Furthermore referred to as pesantren

${ }^{2}$ Claire-Marie Hefner, "Models of Achievement: Muslim Girls and Religious Authority in a Modernist Islamic Boarding School in Indonesia," Asian Studies Review 40, no. 4 (1 Oktober 2016): 564-82, https://doi.org/10.1080/10357823.2016.1229266; Ima Amaliah, Tasya Aspiranti, dan Pupung Purnamasari, "The Impact of the Values of Islamic Religiosity to Islamic Job Satisfaction in Tasikmalaya West Java, Indonesia, Industrial Centre," Procedia - Social and Behavioral Sciences, 2nd Global Conference on Business and Social Sciences (GCBSS-2015) on "Multidisciplinary Perspectives on Management and Society", 17- 18 September, 2015, Bali, Indonesia, 211 (25 November 2015): 984-91, https://doi.org/10.1016/j.sbspro.2015.11.131; Saipul Hamdi, Paul J. Carnegie, dan Bianca J. Smith, "The recovery of a non-violent identity for an Islamist pesantren in an age of terror," Australian Journal of International Affairs 69, no. 6 (2 November 2015): 692-710, https://doi.org/10.1080/10357718.2015.1058339.

${ }^{3}$ Hasan calls it the root of Islamic education in Indonesia, which can be understood that other Islamic education such as madrasas and even universities are parent to it. This is inseparable from the results of Dhofier's research which states that pesantren played a big role in the spread of Islamic religious values from centers of power and early Islamic studies. Zamakhsyari Dhofier, Tradisi pesantren: studi pandangan hidup kyai dan visinya mengenai masa depan Indonesia, Cet. 8 rev (Jakarta: LP3ES, 2011); Chairul Anwar dkk., "The Effectiveness of Islamic Religious Education in the Universities: The Effects on the Students' Characters in the Era of Industry 4.0," Tadris: Jurnal Keguruan Dan Ilmu Tarbiyah 3, no. 1 (29 Juni 2018): 77-87, https://doi.org/10.24042/tadris.v3i1.2162.

${ }^{4}$ Hamid Fahmy Zarkasyi, "Imam Zarkasyi’s Modernization of Pesantren in Indonesia (A Case Study of Darussalam Gontor)," QIJIS (Qudus International Journal of Islamic Studies) 8, no. 1 (2020): 161-200.

${ }^{5}$ Gamal Abdul Nasir Zakaria, "Pondok pesantren: changes and its future," Journal of Islamic and Arabic Education 2, no. 2 (2010): 45-52.

${ }^{6}$ Karel A. Steenbrink, Pesantren Madrasah Sekolah (Jakarta: LP3ES, 1994), 63.

${ }^{7}$ Rustam Ibrahim, "Eksistensi pesantren Salaf di tengah arus pendidikan modern," Analisa: Journal of Social Science and Religion 21, no. 2 (2014): 253-63.

8 Azyumardi Azra, Surau: Pendidikan Islam Tradisional dalam Transisi dan Modernisasi (Logos: Jakarta, 2003), 149. 
religious and general science lessons in the classroom as well as morality, mental and work skills outside the classroom, to changing ownership status from private (foundation) to $W a q f$.

The changes mentioned above now show that pesantren is no longer based on the traditional Islamic education model in the form of talaqqi, and only reads turath books, as well as holsters at every opportunity or focuses solely on Islamic religious Education. The flow of modernization thinking thus gives a new color to the Pesantren system even with the same purpose as the discursion of Islamic Education in general, namely efforts that are not only oriented in the afterlife, namely forming a servant who is obedient to God, but also oriented to the worldly, who can face change and benefit for society ${ }^{10}$.

Along with the modernization that took place in Pesantren, it also appeared precisely in the late $20^{\text {th }}$-century version of Jenks, ${ }^{11}$ a thought movement is known as Postmodernism, which had a core of rejecting everything that smelled absolute and raw. This thought movement continues to shake up thinking that no longer focuses on rationality and creates the thought of relativism, even leading to nihilism. ${ }^{12} \mathrm{It}$, approved or not, has entered into the joints of human life both positively and negatively including Education. Hidayat argues that while it is difficult to find a postmodern connection with the world of Education explicitly but implicitly the big themes that are brought in-such as resistance to absolute attitudes and wanting relativity, actually have many implications, among which is the shift of Education towards a more democratic one with the active participation of the community in the implementation of Education in the areas shown by Law No.20/2003 on the National Education System. That, a little bit, can be understood as a protest against absolutistic which are usually present in teachers or schools against students, so it must present an assessment from the wider community. ${ }^{13}$

Rahman, in other articles, even expressly stated that the postmodernism era is a major challenge facing the education world because he can list the core foundations of character building that became the big idea of Education. ${ }^{14}$ At that point Pesantren should also be the object of discussion because he played a big role in the character building of Indonesian society as Syafe'I, ${ }^{15}$ Zuhry, ${ }^{16}$ and Sumardi had reviewed. ${ }^{17}$ Unfortunately, the paper that

9 Mahrus As'ad, "Tajdīd Al-Tarbīyah al-Islāmīyah ‘inda al-Shaykh al-H̄ājj Imam Zarkasyi," Studia Islamikea 22, no. 2 (31 Agustus 2015): 333-68, https://doi.org/10.15408/sdi.v22i2.1922; Hamid Fahmy Zarkasyi, "Appraising the Moderation Indonesian Muslims with Special Reference to Muhammadiyah and Nahdlatul Ulama," Addin 12, no. 1 (2018): 1-30, https://www.neliti.com/publications/272038/appraising-the-moderationindonesian-muslims-with-special-reference-to-muhammadi.

10 Zaenal Arifin, "Kepemimpinan Kiai Dalam Ideologisasi Pemikiran Santri Di Pesantren-Pesantren Salafiyah Mlangi Yogyakarta," INFERENSI: Jurnal Penelitian Sosial Keagamaan 9, no. 2 (1 Desember 2015): 35172, https://doi.org/10.18326/infsl3.v9i2.351-372; Zakaria, "Pondok pesantren: changes and its future"; Naufal Ahmad Rijalul Alam, "Strengthening Leadership Culture (The Role of Kyai in Indonesian Pesantren)," At-Ta'dib 13, no. 1 (2018): undefined-undefined, https://doi.org/10.21111/at-tadib.v13i1.1986.

${ }^{11}$ Chris Jenks, Culture: Studi Kebudayaan (Yogyakarta: Pustaka Pelajar, 2013), 202.

12 I Bambang Sugiharto, Postmodernisme: Tantangan bagi Filsafat (Kanisius, 1996), 23-28.

13 Ainur Rahman Hidayat, "Implikasi postmodernisme dalam pendidikan," TADRIS: Jurnal Pendidikan Islam 1, no. 1 (2006).

${ }^{14}$ Fathur Rahman, "Tantangan Pendidikan di Era Postmodernisme," Al-Riwayah: Jurnal Kependidikan 9, no. 2 (2017): 323-48.

15 Imam Syafe'i, "Pondok pesantren: Lembaga pendidikan pembentukan karakter," Al-Tadrkizyyab: Jurnal Pendidikan Islam 8, no. 1 (2017): 61-82. 
appears instead recommends that Pesantren change its paradigm following Postmodernism thinking to survive in the era of Postmodernism itself by stating that the paradigm shift is a step towards an ideal education, ${ }^{18}$ without any criticism in it.

When referring to the modern terms that exist in Pesantren, not all of its paradigms are accepted in such traditional institutions. An illustration is what Ahmed points out to modern translation in Muslim thinkers. First, historically, it was the post-traditionalism conditions, and circumstances of dictatorship, coups, corruption and political nepotism. He is also of a low standard in the sphere of Education because it becomes an intellectual parasite with values that are used as having a universal context. Second, he was called an intellectual parasite also for trying to sue, even branding previous religious thought, which developed within the traditionalist paradigm, under the pretext of renewal and renewal ${ }^{19}$. All of that refers to the motivation of mastering Western Education, technology and industrialization. ${ }^{20}$ Based on that, and looking at gontor experience that has been confiscated at a glance before, certainly many sides of the modern paradigm that got criticism from the scope of Pesantren ${ }^{21}$.

Departing from the illustration above, this article wants to see how Pesantren is located, especially Modern in the postmodern era. The question asked is if modernism as a movement of thought is acceptable even with a critical record by the traditional institution, how is it with the postmodernism movement that is happening now, is it having an impact or impacting? The related information will all be traced through library methods; both descriptions, comparisons, and interpretations, which are sourced from documents in the form of books or scientific research articles. In that case, in summary, this research can also be called qualitative research, with researchers as a key instrument ${ }^{22}$ that gives an interpretation of the existence of Modern Pesantren education in the era of Postmodernism.

\section{DISCUSSION AND ANALYSIS}

\section{Postmodernism and the World of Education}

Postmodernism as a term, in Moran's description, was first introduced by Rudolf Panwitz, 1947, through his book Die Crisis der Europais Chen Culture (European Cultural Crisis). In his work, the German philosophize explains the healthy, strong, nationalist, and religious human beings that arise from the thought of European nihilism. At that time, in the historical record, there was a decadent nihilism which was a form of chaos caused by modernity with a picture of the state of society in the world war. From his lengthy explanation, it is concluded

16 M Syaifuddien Zuhriy, "Budaya pesantren dan pendidikan karakter pada pondok pesantren salaf," Walisongo: Jurnal Penelitian Sosial Keagamaan 19, no. 2 (2011): 287-310.

${ }^{17}$ Kamin Sumardi, "Potret Pendidikan Karakter di Pondok Pesantren Salafiah," Jurnal Pendidikan Karakter, no. 3 (2012).

18 Khoiriyah Khoiriyah dan Aries Dirgayunita, "PESANTREN DALAM MENUJU PENDIDIKAN IDEAL DI ERA POSTMODERN,” Imtiyaz: Jurnal Ilmu Keislaman 2, no. 1 (2018): 46-60.

${ }^{19}$ Muhammad Yusuf dan Ismail Suardi Wekke, "Active Learning on Teaching Arabic for Special Purpose in Indonesian Pesantren," Procedia - Social and Behavioral Sciences, The Proceedings of 6th World Conference on educational Sciences, 191 (2 Juni 2015): 137-41, https://doi.org/10.1016/j.sbspro.2015.04.245.

${ }^{20}$ Akbar S. Ahmed, Postmodernisme: Bahasa dan Harapan Bagi Islam (Bandung: Mizan, 1992), 46-48.

${ }^{21}$ Wahyuddin Halim, "Young Islamic preachers on Facebook: Pesantren As'adiyah and its engagement with social media," Indonesia and the Malay World 46, no. 134 (2 Januari 2018): 44-60, https://doi.org/10.1080/13639811.2018.1416796.

22 John W. Creswell, Penelitian Kualitatif dan Desain Riset (Yogyakarta: Pustaka Pelajar, 2014). 
that Postmodernism is necessary. ${ }^{23}$ Philosophically, Lyotard was considered a figure who first published it, namely through a French-language work called La Condition Postmodern Report Sur Le Savoir recorded in The Postmodern Condition. ${ }^{24}$ In his study, it was seen that the main thought of Postmodernism was to reject the basic idea of modern philosophy of principled unity or globalization. Toynbee noted it all as a long history of thought in his famous book titled $A$ Study of History, Introduction: The Geneses of Civilizations. ${ }^{25}$

As a thought movement, Postmodernism is not fully agreed upon by its experts. Ryadi calls it a confusion laying out the term post before modernism that raises many questions. Whether the post is a total disconnection of thought from everything related to modern thought patterns as called Lyotard, or precisely corrections to the various major themes of thought brought about by modernization such as Griffin's theory, or also the opinion that calls Postmodernism a radical form of the modernization thought movement itself, which in Derrida's narrative, is called will end in suicide, or just a new face that looks more mature as Giddens conveys, or just an unfinished modernization movement as Habermas delivers. The uncertain narrative developed makes postmodernism thinkers themselves confused about the direction and purpose of their thinking. ${ }^{26}$ The interesting thing is that it can be understood because Postmodernism is a movement that rejects certainty so that the terminological definition of their own thought movement cannot be ascertained in its entirety.

Thus, borrowing analysis from Ilham that examines Postmodernism theoretically and analytically, something that influences many of these thought movements is the paradigm it offers. ${ }^{27}$ The paradigm in question is a radical critique of Western philosophy that tends to put aspects of rationalism as a principle in the field of science and science. It is also seen as an attitude, a general culture, that deals with narratives of relativity, anti-universality, nihilism, criticism of rationalism and fundamentalism or science, as well as a general reaction to modern rationalism, utopianism, and what was then referred to as "foundationalism", an attempt to build the foundation of knowledge and judgment that has been the concern of the philosophy since Rene Descartes's time in the 17 th century. ${ }^{28}$

Thus, the interconnectedness of Postmodernism with the world of Education is actually similar to the relationship of philosophy with the world of Education. How the paradigm, perspective, point of view, conceptual framework, frame of thinking, analytical framework, school of thought, and approach in the world of Education are the objects of its work. Even if Ahimsa mentions there are 9 (Nine) paradigm elements ${ }^{29}$, then in the first point;

23 Dermot Moran, Husserl's crisis of the European sciences and transcendental phenomenology: An introduction (Cambridge University Press, 2012).

${ }^{24}$ Jean-François Lyotard, The postmodern condition: A report on knowledge, vol. 10 (U of Minnesota Press, 1984).

25 Arnold J Toynbee, A Study of History: Volume I: Abridgement of Volumes I-VI, vol. 1 (Oxford Paperbacks, 1987).

${ }^{26}$ Agustinus Ryadi, "Postmodernisme versus modernisme," Studia Philosophica et Theologica 4, no. 2 (2004): 91.

${ }^{27}$ Iromi Ilham, "Paradigma Postmodernisme; Solusi untuk Kehidupan Sosial?," Jurnal Sosiologi USK (Media Pemikiran \& Aplikasi) 12, no. 1 (2018): 1-23.

28 Ilham, 5-6.

${ }^{29}$ Sembilan paradigma yang dimaksud adalah asumsi-asumsi dasar, nilai-nilai (values), masalah yang ingin diteliti, model, konsep-konsep, metode penelitian, metode analisis, hasil analisis, dan etnografi atau representasi. Baca selengkapnya di Putra Ahimsa, "Paradigma Ilmu Sosial-Budaya; Sebuah Pandangan," Kuliah Umum Paradigma Penelitian Ilmu-Ilmu Humaniora (Bandung, 2009), 4. 
The basic assumptions, Postmodernism is already very influential, namely when the values of truth are seen relatively, so that the great narratives that thinkers once put forward, to western origin though, are seen instead of being able to make the world better, instead of making the state of the world even more chaotic. ${ }^{30}$

Not surprisingly, as previously confiscated, Rahman expressly stated that the postmodernism era was a major challenge facing the education world. That's because a paradigm and cultural attitude can exist the core foundations of character building that become the big idea of organizing Education. ${ }^{31}$ In a broader scope including in Islam, he is also seen as threatening the existence of sacred religious values as a result of the spectacle of deconstruction to the nihilism he brings. More or less, in the historical state, this movement of thought is also a response to traditional Christian religious doctrine, ${ }^{32}$ or even tends to westernization. ${ }^{33}$

Nevertheless, looking at the movement of Postmodernism thinking above from the negative side is certainly not a wise choice. Villia in his serious working paper in the form of a thesis at Maulana Malik Ibrahim State Islamic University Malang, 2005, concluded that the discourse born postmodernism is very relevant to the campus environment especially in terms of academic freedom and gender equality ${ }^{34}$. He stated in the conclusion that postmodernism thinking is motivated by different types of values (receptive, achievement, actualization. or donation) with the realization that everyone is creatively created. The movement of thought, in the field of Education, gives a broader choice in the development of aspects of intelligence to the integration between intellectual, emotional and spiritual. For students, he gives them more space to develop themselves as subjects and not educational objects. In terms of free speech, the discourse also includes the freedom to write, research, produce scientific works, create scientific forums and institutions, convey opinions, thoughts and ideas within a set academic framework. In gender equality, Postmodernism is considered to apply fair conditions for women and men in realizing themselves in the world of Education. ${ }^{35}$

\section{Modern Islamic Boarding School and Postmodernism}

It has been explained at the beginning that Pesantren is a traditional educational institution in Indonesia. Its existence as a traditional educational institution (salaf) is heavily influenced by kyai's existence as a central figure who leads while guiding students in optimizing its potential, as well as utilizing dormitories as an education system, and mosques

\footnotetext{
30 Ilham, "Paradigma Postmodernisme; Solusi untuk Kehidupan Sosial?," 10.

${ }^{31}$ Rahman, "Tantangan Pendidikan di Era Postmodernisme."

32 Abdul Mukti Ro'uf, "Posmodernisme: Dampak dan Penerapannya pada Studi Islam," Analisis: Jurnal Studi Keislaman 19, no. 1 (2019): 155-76.

33 Yusuf Ismail, "Postmodernisme dan Perkembangan Pemikiran Islam Kontemporer," Jurnal Studi AlQur'an 15, no. 2 (2019): 235-48.

${ }^{34}$ Husniyatus Salamah Zainiyati, "Landasan Fondasional Integrasi Keilmuan di UIN Maulana Malik Ibrahim Malang dan UIN Sunan Ampel Surabaya," ISLAMICA: Jurnal Studi Keislaman 10, no. 1 (29 Agustus 2016): 248-76, https://doi.org/10.15642/Islamica.2015.10.1.248-276.

${ }^{35}$ Lativa Latansa Villia, "Wacana Postmodernisme dan relevansinya terhadap Pendidikan Agama Islam di Perguruan Tinggi Islam: Eksplorasi Diskursif Mengenai Kebebasan Akademik Dan Kesetaraan Gender di Universitas Islam Negeri Maulana Malik Ibrahim Malang dan Universitas Muhammadiyah Malang" (Universitas Islam Negeri Maulana Malik Ibrahim, 2016), 179-82.
} 
as the center of pesantren activities themselves ${ }^{36}$. Armed with religious lessons, traditional education organizing in Pesantren took place and gave the results. ${ }^{37}$. If Madjid discusses it as an Indonesian indigenous institution, ${ }^{38}$ then Rasyidin states it as a symbol of the correlation between Education and civilization in Indonesia. ${ }^{39}$

Modernization is then done. He, in Azra's description, is key to the persistence of Pesantren amid the rapid flow of the emergence of different Islamic educational institutions. ${ }^{40}$ A little bit, the influence of the globalization thought movement does exist in that. ${ }^{41}$ But also worth remembering is wahid's words that many researchers agreed on the identity of Pesantren, the subculture of Indonesian society ${ }^{42}$, with which it can be understood that he is an inseparable cultural unit and a part of people's own life. It is dynamic, changeable, and has strong argumentative fundamentals to drive change to its intended purpose. Siradj clarified the statement in his two descriptions on the background of the presence of Pesantren, firstly in response to the situation and condition of society at the time that was collapsing its moral and ethical joints due to social change, the second as an attempt to disseminate the teachings of Islamic universality throughout the archipelago. ${ }^{43}$ At that point, precisely the data presented by Mas'ud or Siridjo who mentioned Maulana Malik Ibrahim or Sheikh Maulana Maghribi (d. 12 Rabiul awal 822 H/3 April 1419) was a pioneer of the existence of Pesantren, which is when he led the da'wah effort in the 14th century in Java with some of his friends and settled in Gresik City, designate a muballigh, then known as Wali. ${ }^{44}$

Regarding its modernization, a fairly complete picture of it can be seen from Zarkasyi's article that has been introduced. ${ }^{45}$ In his writing stipulated that the idea of modernization carried out by Modern Darussalam Gontor Islamic Boarding School Ponorogo is inseparable from the thoughts, educational experience, and religious tendencies of Imam Zarkasyi. "... This paper identifies that the educational thought and experiences of Imam Zarkasyi, as well as his religious inclination, played an important role in his modernization of pesantren ...", ${ }^{46}$ Of these three factors were then born three realms of modernization, namely

36 Muhammad Anas Ma arif dan Ibnu Rusydi, "IMPLEMENTASI PENDIDIKAN HOLISTIK DI PONDOK PESANTREN AMANATUL UMMAH MOJOKERTO,” EDUKASI: Jurnal Penelitian Pendidikan Agama Dan Keagamaan 18, no. 1 (27 April 2020), https://doi.org/10.32729/edukasi.v18i1.598.

37 Panitia Penyusunan Riwayat Hidup, Biografi KH Imam Zarkasyi: Dari Gontor Merintis Pesantren Modern (Ponorogo: Gontor Press, 1996), 51.

${ }_{38}$ Nurcholis Madjid, Bilik-BIlik Pesanten, Sebuah Potret Perjalanan (Jakarta: Paramadina, 1997), 17.

39 Rasyidin Rasyidin, "PONDOK PESANTREN: SIMBOL KORELASI DAN KONEKSI PENDIDIKAN DAN PERADABAN DALAM NARASI SEJARAH ISLAM DI INDONESIA,” Babsun Imi 1, no. 1 (2020): 1-14.

40 Azra, Surau: Pendidikan Islam Tradisional dalam Transisi dan Modernisasi, 149.

41 Bashori Bashori, "Modernisasi lembaga pendidikan pesantren," Jurnal Ilmu Sosial Mamangan 6, no. 1 (2017): 47-60.

${ }^{42}$ Abdurrahman Wahid, Menggerakekan Tradisi, Esai-Esai Pesantren (Yogyakarta: LKiS, 2001), 10.

${ }^{43}$ Said Aqil Siradj, Pesantren Masa Depan, Wacana Pemberdayaan dan Transformasi Pesantren (Bandung: Pustaka Hidayah, 1999), 202.

44 Abdurrachman Mas'ud, Dinamika Pesantren dan Madrasah (Yogyakarta: Pustaka Pelajar, 2002), 248; Marwan Saridjo, Pendidikan Islam dari Masa ke Masa: Tinjanan Kebijakan Terbadap Pendidikan Islam di Indonesia (Jakarta: Yayasan Ngali Aksara, 2010), 17-30.

45 Zarkasyi, "Imam Zarkasyi's Modernization of Pesantren in Indonesia (A Case Study of Darussalam Gontor)."

46 Zarkasyi, 161. 
those in the area of Education, curriculum and institutional system. ${ }^{47}$ First, integrate the (traditional) Pesantren system with madrassas. Second, integrate formal and informal Education in Pesantrens and teach religious and general science lessons in the classroom as well as morality, mental and work skills outside the classroom, and a third change ownership status from private (foundation) to $\mathrm{Waqf}^{48}$

Furthermore, concerning Postmodernism as a movement of thought discussed deeply in this article, then actually the view of thought is also the cornerstone of modernization of Pesantren a la Imam Zarkasyi above. His expression during the reception of the half-century gratitude of Modern Darussalam Gontor Islamic Boarding School and the Inauguration of Jami' Gontor Mosque can be a reference,

"This Islamic Boarding School (pesantren) is an Islamic educational institution like any other institution. The difference is in the teaching method. We use modern teaching methods by not teaching anything new in religion. This Pesantren is also a waqf for Muslims, which means it belongs to the people and does not belong to Kiai anymore. This cottage does not lean towards any political party, therefore its motto is To stand above and for all factions. The purpose of his Education is to produce a Muslim who is noble, able-bodied, well-educated, and self-sufficient".

The final purpose of this cottage is li i'lấi kalimatillahb, ${ }^{49}$ Steenbrink judges the phrase is Gontor's defensive attitude to the strong roots of the traditionality of educational institutions although by taking another path in the form of modernity. ${ }^{50}$

The dutch scholar's assessment above is actually a choice of attitudes that actually come from Pesantren over the influences of existing thinking. In the broader scene, a thought will always have an influence. ${ }^{51}$ However, in the case of Islamic Education, Education is the one that should be cleaned from the influences that damage themselves. ${ }^{52}$ Arif states it as the theory of interdependence, which is when everything will be affected by other things, but each thing will also have a characteristic, unique element, which is impossible to fertile or unable to develop on other things. ${ }^{53}$

Returning to the Postmodernism thought movement thus, illustrated the strong relevance between Pesantren and the Postmodernism thought movement, especially in Habermas glasses. The last so-called name in Nugroho's research does tend to refer to the movement that emerged in the late 20th century by referring to it as another naming of unfinished modernism. ${ }^{54}$ Postmodernism thus considers it simply dialectics to be done to gain enlightenment over various problems unresolved by modernism that have a background in enlightenment as well. In Die Moderne ein Unvollendetes Projekt he asserts his principle in the face

${ }^{47}$ Zarkasyi, 192-93.

48 Zarkasyi, 193.

49 Zarkasyi, 179.

50 Steenbrink, Pesantren Madrasah Sekolah, 14.

51 Sebagai contoh kecil adalah pengaruh filsafat iluminasi dalam dunia Pendidikan Islam yang pernah dinyatakan Harahap dalam artikelnya Radinal Mukhtar Harahap, "Pengaruh Filsafat Iluminasi Dalam Pemikiran Pendidikan Islam," Jurnal Penelitian Medan Agama 10, no. 1 (2019).

52 Wan Daud, Peranan Universiti: Pengislaman Ilmu Semasa, Penafibaratan dan Penafijajahan (Kuala Lumpur: Casis-Hakim, 2017).

${ }^{3}$ Syamsuddin Arif, “"Transmigrasi Ilmu’: Dari Dunia Islam ke Eropa,” TSAQAFAH 6, no. 2 (2010): 199_ 213.

54 Heru Nugroho, "Kritik Habermas Terhadap Postmodernisme dan Relevansinya bagi Pemahaman Pembangunan,” UNISIA, no. 32 (2016): 24-32. 
of Postmodernism by understanding that modernity is a work that is not or is not finished so that the flourish is a continuation of modernity itself. ${ }^{55}$ For the scope of Pesantren it should also be understood that the institution is still traditionalist, despite taking the path of modernity even to postmodernity. Adagium fiqh al-muhâfazâh 'alâ al-qadîm al-shâlih wa al-akhæun bi al-jadîd al-ashlab is the logical argument about it.

Some of the following aspects can be illustrated. First, Pesantren in the early days was always synonymous with the lessons of religion, especially jurisprudence of jurisprudence; In terms of methodology, sorogan and wetonan are the choices in organizing Education. Imam Zarkasyi as a figure who modernized Pesantren had an experience of Education as is generally Pesantren in the early days. However, when it comes to modernization, he gives appreciation as well as criticism of it. He sees that the recitation of the books of fission such as fath al-Qarib or fath al-Mu'in does not give many aspect of understanding unless the reader understands Arabic. "... I think it's better that I understand Arabic first than read a book. So why don't I learn Arabic just yet? " ${ }^{56}$ Nevertheless, it is important to underline that his criticism is also accompanied by appreciation because he does not abandon the traditional aspects that have existed. The committee that wrote his biography noted that the curriculum built by Imam Zarkasyi in the early days consisted of three levels, while still pinning the book of fath al-Qarîb or fath al-Mu'in in it. $^{57}$

Second, related to the existence of general science juxtaposed with religious science in Pondok Modern. On the one hand, it can be understood as a form of modernity initiated by Imam Zarkasyi. However, on the other hand, the integration of science is an echo of Postmodernism even with the end of spiritualistic meaning even without religion, which flourished in the West. Seyyed Hossein Nasr in Mahmud's notes judged that the opinion was utopian because of the spirituality that in the past has proven to be predominantly religious so that it will re-emerge in the future so that more appropriate is the religion of the future is the religion of the past and present. ${ }^{58}$

Third, about the institutional aspect. The modernization of Imam Zarkasyi in this case is to change the ownership status of the person (foundation) to the $W$ aqf. The statement can be understood in the context of the influence of Postmodernism that rejects absolute things such as kyai policy which is absolutely $100 \%$ applicable in Pesantren. Imam Zarkasyi considers that the continuity of educational institutions will not be guaranteed if only owned by individuals or families. It will have a devastating impact if there is no figure from any family member who can continue the continuity of the institution. Therefore, Pesantren must be converted so that it no longer belongs to the founding individual or his descendants. In the case of the PMDG that Zarkasyi researched, the institute selected 15 people as members of the $W$ aqf Board stating in writing that after the death of the founders they should be responsible for the succession of leadership of Pesantren. ${ }^{59}$

55 Jürgen Habermas, Die Moderne ein Unvollendetes Projekt (Leipziq: Reclam-Verlag, 1990), 32-54.

56 Zarkasyi, "Imam Zarkasyi's Modernization of Pesantren in Indonesia (A Case Study of Darussalam Gontor)," 176.

${ }^{57}$ Panitia Penyusunan Riwayat Hidup, Biografi KH Imam Zarkasyi: Dari Gontor Merintis Pesantren Modern, 46.

${ }^{58}$ Natsir Mahmud, Epistemologi dan Studi Islam Kontemporer (Makassar: PPIM IAIN Alauddin, 2002), 40.

59 Zarkasyi, "Imam Zarkasyi's Modernization of Pesantren in Indonesia (A Case Study of Darussalam Gontor)," 192. 


\section{CONCLUSION}

Thus, to answer whether Pesantren was affected or affected by the Postmodernism thought movement has the same answer as the state of modernism and Pesantren. The only lexicality in the form of renewal only appears to the surface. In principle, characteristic or basic values, Pesantren remains an institution reading in the body of Islamic education thinking. The principle is tafaqqub fi ad-din. The principle is the creation of a perfect human being (insân kâmil). Its characteristics are kiai, mosque, dormitory, santri, and yellow book (kitab kuning). As for the basic values, he developed are Islamic religious values that develop in society.

As for the development of thought, whether related to modernism or Postmodernism, something good (al-ashlab) from it is what Pesantren takes to keep the good (al-shalih) in its traditions. It is also noted that the tradition that appears to be surface and is considered similar to other thought movements such as the use of classes, the use of clothes that are no longer scabbards, the implementation of Education that is no longer wetonan and sorogan or the absorption of secular sciences and life skills, is a dynamic attitude that is so inherent in the Pesantren environment. Finally, regarding Waqf, which is the basis of ownership in Pesantren, which replaces the Foundation system is not new, so it is concluded not to exist in Islamic tradition. The Waqf is actually to return the request of something to God. Therefore, it can also be understood that Pesantren, with its rapid development at all times, still returns to the traditions of existing Islamic educational institutions, which aim to give the life and afterlife of everyone related to it, without turning a blind eye to the development in the world itself.

\section{REFERENCES}

Ahimsa, Putra. "Paradigma Ilmu Sosial-Budaya; Sebuah Pandangan." Kuliah Umum Paradigma Penelitian Ilmu-Ilmu Humaniora. Bandung, 2009.

Ahmed, Akbar S. Postmodernisme: Babasa dan Harapan Bagi Islam. Bandung: Mizan, 1992.

Alam, Naufal Ahmad Rijalul. "Strengthening Leadership Culture (The Role of Kyai in Indonesian Pesantren)." At-Ta'dib 13, no. 1 (2018): undefined-undefined. https://doi.org/10.21111/at-tadib.v13i1.1986.

Amaliah, Ima, Tasya Aspiranti, dan Pupung Purnamasari. "The Impact of the Values of Islamic Religiosity to Islamic Job Satisfaction in Tasikmalaya West Java, Indonesia, Industrial Centre." Procedia - Social and Behavioral Sciences, 2nd Global Conference on Business and Social Sciences (GCBSS-2015) on "Multidisciplinary Perspectives on Management and Society", 17- 18 September, 2015, Bali, Indonesia, 211 (25 November 2015): 984-91. https://doi.org/10.1016/j.sbspro.2015.11.131.

Anwar, Chairul, Antomi Saregar, Uswatun Hasanah, dan Widayanti Widayanti. "The Effectiveness of Islamic Religious Education in the Universities: The Effects on the Students' Characters in the Era of Industry 4.0." Tadris: Jurnal Keguruan Dan Ilmu Tarbiyah 3, no. 1 (29 Juni 2018): 77-87. https://doi.org/10.24042/tadris.v3i1.2162.

Arif, Syamsuddin. “Transmigrasi Ilmu': Dari Dunia Islam ke Eropa.” TSAQAFAH 6, no. 2 (2010): 199-213.

Arifin, Zaenal. "Kepemimpinan Kiai Dalam Ideologisasi Pemikiran Santri Di PesantrenPesantren Salafiyah Mlangi Yogyakarta." INFERENSI: Jurnal Penelitian Sosial 
Keagamaan 9, no. 2 (1 Desember 2015): $351-72$. https://doi.org/10.18326/infsl3.v9i2.351-372.

As'ad, Mahrus. "Tajdīd Al-Tarbīyah al-Islāmīyah 'inda al-Shaykh al-Ḥājj Imam Zarkasyi." Studia Islamika 22, no. 2 (31 Agustus 2015): 333-68. https://doi.org/10.15408/sdi.v22i2.1922.

Azra, Azyumardi. Surau: Pendidikan Islam Tradisional dalam Transisi dan Modernisasi. Logos: Jakarta, 2003.

Bashori, Bashori. "Modernisasi lembaga pendidikan pesantren." Jurnal Ilmu Sosial Mamangan 6, no. 1 (2017): 47-60.

Creswell, John W. Penelitian Kualitatif dan Desain Riset. Yogyakarta: Pustaka Pelajar, 2014.

Daud, Wan. Peranan Universiti: Pengislaman Ilmu Semasa, Penafibaratan dan Penafijajahan. Kuala Lumpur: Casis-Hakim, 2017.

Dhofier, Zamakhsyari. Tradisi pesantren: studi pandangan hidup kyai dan visinya mengenai masa depan Indonesia. Cet. 8 rev. Jakarta: LP3ES, 2011.

Habermas, Jürgen. Die Moderne ein Unvollendetes Projekt. Leipziq: Reclam-Verlag, 1990.

Halim, Wahyuddin. "Young Islamic preachers on Facebook: Pesantren As'adiyah and its engagement with social media." Indonesia and the Malay World 46, no. 134 (2 Januari 2018): 44-60. https://doi.org/10.1080/13639811.2018.1416796.

Hamdi, Saipul, Paul J. Carnegie, dan Bianca J. Smith. "The recovery of a non-violent identity for an Islamist pesantren in an age of terror." Australian Journal of International Affairs 69, no. $60 \quad 2 \quad$ November 2015): https://doi.org/10.1080/10357718.2015.1058339.

Harahap, Radinal Mukhtar. "Pengaruh Filsafat Iluminasi Dalam Pemikiran Pendidikan Islam." Jurnal Penelitian Medan Agama 10, no. 1 (2019).

Hefner, Claire-Marie. "Models of Achievement: Muslim Girls and Religious Authority in a Modernist Islamic Boarding School in Indonesia." Asian Studies Review 40, no. 4 (1 Oktober 2016): 564-82. https://doi.org/10.1080/10357823.2016.1229266.

Hidayat, Ainur Rahman. "Implikasi postmodernisme dalam pendidikan." TADRIS: Jurnal Pendidikan Islam 1, no. 1 (2006).

Ibrahim, Rustam. "Eksistensi pesantren Salaf di tengah arus pendidikan modern." Analisa: Journal of Social Science and Religion 21, no. 2 (2014): 253-63.

Ilham, Iromi. "Paradigma Postmodernisme; Solusi untuk Kehidupan Sosial?" Jurnal Sosiologi USK (Media Pemikiran \& Aplikasi) 12, no. 1 (2018): 1-23.

Ismail, Yusuf. "Postmodernisme dan Perkembangan Pemikiran Islam Kontemporer." Jurnal Studi Al-Qur'an 15, no. 2 (2019): 235-48.

Jenks, Chris. Culture: Studi Kebudayaan. Yogyakarta: Pustaka Pelajar, 2013.

Khoiriyah, Khoiriyah, dan Aries Dirgayunita. "PESANTREN DALAM MENUJU PENDIDIKAN IDEAL DI ERA POSTMODERN." Imtiyaz: Jurnal Ilmu Keislaman 2, no. 1 (2018): 46-60.

Lyotard, Jean-François. The postmodern condition: A report on knowledge. Vol. 10. U of Minnesota Press, 1984.

Ma`arif, Muhammad Anas, dan Ibnu Rusydi. "IMPLEMENTASI PENDIDIKAN HOLISTIK DI PONDOK PESANTREN AMANATUL UMMAH 
MOJOKERTO.” EDUKASI: Jurnal Penelitian Pendidikan Agama Dan Keagamaan 18, no. 1 (27 April 2020). https://doi.org/10.32729/edukasi.v18i1.598.

Madjid, Nurcholis. Bilik-BIlik Pesanten, Sebuah Potret Perjalanan. Jakarta: Paramadina, 1997.

Mahmud, Natsir. Epistemologi dan Studi Islam Kontemporer. Makassar: PPIM IAIN Alauddin, 2002.

Mas'ud, Abdurrachman. Dinamika Pesantren dan Madrasah. Yogyakarta: Pustaka Pelajar, 2002.

Moran, Dermot. Husserl's crisis of the European sciences and transcendental phenomenology: An introduction. Cambridge University Press, 2012.

Nugroho, Heru. "Kritik Habermas Terhadap Postmodernisme dan Relevansinya bagi Pemahaman Pembangunan." UNISLA, no. 32 (2016): 24-32.

Panitia Penyusunan Riwayat Hidup. Biografi KH Imam Zarkasyi: Dari Gontor Merintis Pesantren Modern. Ponorogo: Gontor Press, 1996.

Rahman, Fathur. "Tantangan Pendidikan di Era Postmodernisme." Al-Riwayah: Jurnal Kependidikan 9, no. 2 (2017): 323-48.

Rasyidin, Rasyidin. "PONDOK PESANTREN: SIMBOL KORELASI DAN KONEKSI PENDIDIKAN DAN PERADABAN DALAM NARASI SEJARAH ISLAM DI INDONESIA." Babsun Ilmi 1, no. 1 (2020): 1-14.

Ro'uf, Abdul Mukti. "Posmodernisme: Dampak dan Penerapannya pada Studi Islam." Analisis: Jurnal Studi Keislaman 19, no. 1 (2019): 155-76.

Ryadi, Agustinus. "Postmodernisme versus modernisme." Studia Philosophica et Theologica 4, no. 2 (2004): 90-100.

Saridjo, Marwan. Pendidikan Islam dari Masa ke Masa: Tinjauan Kebijakan Terbadap Pendidikan Islam di Indonesia. Jakarta: Yayasan Ngali Aksara, 2010.

Siradj, Said Aqil. Pesantren Masa Depan, Wacana Pemberdayaan dan Transformasi Pesantren. Bandung: Pustaka Hidayah, 1999.

Steenbrink, Karel A. Pesantren Madrasah Sekolah. Jakarta: LP3ES, 1994.

Sugiharto, I Bambang. Postmodernisme: Tantangan bagi Filsafat. Kanisius, 1996.

Sumardi, Kamin. "Potret Pendidikan Karakter di Pondok Pesantren Salafiah." Jurnal Pendidikan Karakter, no. 3 (2012).

Syafe'i, Imam. "Pondok pesantren: Lembaga pendidikan pembentukan karakter." AlTadzkiyyah: Jurnal Pendidikan Islam 8, no. 1 (2017): 61-82.

Toynbee, Arnold J. A Study of History: Volume I: Abridgement of Volumes I-VI. Vol. 1. Oxford Paperbacks, 1987.

Villia, Lativa Latansa. "Wacana Postmodernisme dan relevansinya terhadap Pendidikan Agama Islam di Perguruan Tinggi Islam: Eksplorasi Diskursif Mengenai Kebebasan Akademik Dan Kesetaraan Gender di Universitas Islam Negeri Maulana Malik Ibrahim Malang dan Universitas Muhammadiyah Malang." Universitas Islam Negeri Maulana Malik Ibrahim, 2016.

Wahid, Abdurrahman. Menggerakkan Tradisi, Esai-Esai Pesantren. Yogyakarta: LKiS, 2001.

Yusuf, Muhammad, dan Ismail Suardi Wekke. "Active Learning on Teaching Arabic for Special Purpose in Indonesian Pesantren." Procedia - Social and Behavioral Sciences, The Proceedings of 6th World Conference on educational Sciences, 191 (2 Juni 2015): 137-41. https://doi.org/10.1016/j.sbspro.2015.04.245. 
Zainiyati, Husniyatus Salamah. "Landasan Fondasional Integrasi Keilmuan di UIN Maulana Malik Ibrahim Malang dan UIN Sunan Ampel Surabaya." ISLAMICA: Jurnal Studi Keislaman 10, no. 1 (29 Agustus 2016): 248-76. https://doi.org/10.15642/Islamica.2015.10.1.248-276.

Zakaria, Gamal Abdul Nasir. "Pondok pesantren: changes and its future." Journal of Islamic and Arabic Education 2, no. 2 (2010): 45-52.

Zarkasyi, Hamid Fahmy. "Appraising the Moderation Indonesian Muslims with Special Reference to Muhammadiyah and Nahdlatul Ulama." Addin 12, no. 1 (2018): 1-30. https://www.neliti.com/publications/272038/appraising-the-moderation-indonesianmuslims-with-special-reference-to-muhammadi.

"Imam Zarkasyi's Modernization of Pesantren in Indonesia (A Case Study of Darussalam Gontor)." QIJIS (Qudus International Journal of Islamic Studies) 8, no. 1 (2020): 161-200.

Zuhriy, M Syaifuddien. "Budaya pesantren dan pendidikan karakter pada pondok pesantren salaf." Walisongo: Jurnal Penelitian Sosial Keagamaan 19, no. 2 (2011): 287-310. 